\title{
Introduction to Special Issue: African Artistic Practices and New Media: Intersections, Volatilities, \\ Futures-Issue II \\ Akin Adesokan
}

The articles in the following pages constitute the second of the two special issues of Africa Today based on the interdisciplinary symposium held at the Indiana University European Gateway in Berlin, Germany, in June 2017. Since all the papers were presented together at the two-day symposium, there are no major conceptual differences between these articles and those published in the first special issue (Africa Today 64[4], Summer 2018). Rather, the symposium's central concern with the intersections of various media, locations, and practices receives a catalyzing emphasis in the five articles published here, especially in relation to the volatilities of form, disciplinary knowledge, and institutions.

Vincent Bouchard, in "Audiovisual Production in West Africa," shows how digital shifts in production affect aspects of the cinematographic medium that were once viewed in specifically technical ways. From the artifacts of audiovisual broadcasting to the aesthetic expectations of audiences, important changes occur that necessitate what Bouchard characterizes as "the integration of new technical and aesthetic forms" with the language suited to the canon of film studies. In West Africa, this shift to the digital presents opportunities as well as challenges. Analyzing recent Francophone West African productions, Bouchard questions the aesthetic criteria applied to African cinema. He explores these new aesthetic paths and details how the aesthetic evolution presents challenges for African film studies in general and, more specifically, for audiovisual institutions in West Africa.

Ivo Ritzer reframes African cinema along the lines of a philosophy of relationality in his contribution, "The Relational Politics of Media Culture in the Age of Post-Third Cinema." His approach aligns questions of aesthetics with questions of politics. He eschews Third Cinema's protocol of didactism and realism and posits Post-Third Cinema as an aesthetics of sensible intensities, moving toward a universal understanding of cinematographic art in the age of global media culture. Although he does not prioritize a digital shift as such, his analysis of "global media culture" draws on changes that occur 
in both form and the location of production. Whether or not the protocols of Third Cinema are exhausted is a question still being debated by scholars, and Ritzer's provocative argument is sure to add to the vibrancy of the debate.

For her part, Nadine Siegert focuses on a particular process of imaging. In "Jesus, Che, Luaty: On the Relationship between a Digital Picture and an Iconic Image in Political Iconography in Angola," she analyzes how images of the performer Luaty Beirão (a.k.a. Ikonoklasta a.k.a. Brigadeiro Mata Frakuxz) emerged in the context of a charged political moment in Angola. Luaty Beirão became internationally known as a political activist during his imprisonment in June 2015, when he was accused of challenging the Angolan state with a coup d'état. In analyzing the images of him that circulated at the time, Siegert suggests similarities with Christian iconography, which contributed to making Beirão into an iconic political figure. Politicized images of him, Siegert argues, met a demand for new imagery on behalf of the public opposed to the politics of the state. It is noteworthy that the process of circulation through which Beirão transcends the specifics of Angolan politics shares a rough correspondence with the idea of relationality that Ritzer analyzes in his article.

This correspondence, accidental or not, is noteworthy because it is indicative of the theme of the symposium as generally prospective. In the roundtable that closed off the meeting at the end of the second day, participants discussed issues pertaining to future directions in research, especially in genres that are typically overlooked, and in disciplines not often considered feasible for representational or artistic purposes. The articles by Susanne Gehrmann and Ute Fendler take up two important themes in the first area, focusing on the creative use of new media in romance and superhero comics. In "Remediating Romance: Forms and Functions of New Media in Contemporary Love Stories from Togo and South Africa," Gehrmann tackles new media's impact on literature through an exploration of works-romance and chick lit-in which writers imagine new ways of integrating media and writing. Focusing on the romance subgenre, she uses the concepts of remediation and intermediality as decisive bases of generic transformation between social media and African literature; she shows that, although innovative in different ways, remediated romance remains romance, even as the authors-Chris-Edgar Locoh and Fiona Synckers-succeed in rewriting the genre through remediation.

Superhero comics are the focus of Fendler's speculatively titled essay, "Superheroes for Africa?" In an engaged blend of historical and exegetical readings, she argues that young artists, mainly from Nigeria and South Africa, have created a universe with local, mainly mystic references, in which the figure of the superhero can turn into a model for the potential creativity for local solutions. Then, analyzing a selection of recent comics produced in Mali, Burkina Faso, and Senegal, places that rarely receive attention in academic discourse, she claims that the successes enjoyed by these works are a function of technical refinement and high-end aesthetics. Written before the recent phenomenal success of the Marvel Comics film 
Black Panther, the essay shows an awareness of imaginative possibilities animating the production and circulation of African arts.

These essays all offer cogent arguments for how new media have made a decisive impact on the aesthetic outlook of African art forms and reinforce the spirit of the roundtable closing off the symposium. Speaker after speaker on that roundtable homed in on the rich potential of digitality, on the level of method and insight, in generally speculative and theoretical terms, as well as in terms that can force the reevaluation of disciplinary conventions. In particular, historian Michelle Moyd pointed out how digital culture opens up possibilities in thinking about images of military expeditions and actual deployments of armed forces in war, and in analyzing such images in ways that deepen or complicate historical accounts. Further potential exists in approaching this culture of images from the perspective of a practice tied to old forms of imperialism but now closely framed in terms of discourses about human rights, such as military interventionism and humanitarianism.

It is astonishing to see how well and insistently those open-ended discussions resonate with the arguments set out in the essays printed here. Together, they make for a lively dialogue about the relationships between old and new media, the questions that exercise African artists regarding the locations of production, and the problems of public scholarship, especially for authors who envision their audiences as primarily based on the continent. 